\title{
Feminist activism 25 years after Beijing
}

\section{Maxine Molyneux, Adrija Dey, Malu A. C. Gatto and Holly Rowden}

Young women have taken the lead in a new wave of feminist and democratic protests that have erupted across a wide range of countries, North and South. These movements raise a range of political and analytic questions: to what extent is it useful to identify the recent wave of activism in terms of a new generation of activists? How different is the 'new' Feminism to earlier forms, and what differences and continuities divide and unite the generations? These questions are explored through examining the characteristics common to contemporary feminisms, and through case studies of different campaigns in Brazil, India and Malawi.

Key Words: Feminism, Fourth Wave Feminism, Generation, global social movements,

\section{Introduction}

In 2020, as we mark 25 years since Beijing, feminist activism in both North and South seems to have acquired a renewed dynamism. Across the globe, it seems that it is not only OK but 'cool' to be a feminist. There is something creative and exciting going on, as a new generation of feminists calls out the patriarchy.

Recently, we have seen growing international support for movements like 'Million Women Rise' and the Me Too campaign which have galvanised untold numbers of women across the world to denounce gender-based violence, misogyny and sexual harassment. The Women's Marches and insurgent campaigns around reproductive rights are other instances of these recent mobilisations. In Poland thousands took part in the 'Czarny Protest' (Black Protest) to oppose attempts by the ruling PIS party to remove women's access to legal abortions. In India, angry demonstrations against gang rapes and police sexual violence have taken place. Similarly, since 2018, tens of thousands of women have taken to the streets in Latin America in the Ni Una Menos (Not One Less) campaign to protest the lack of government response to violence against women (VAW). In the Post-Soviet world, there have been eruptions of feminist protest of different kinds: in Russia, Pussy Riot, and in Ukraine, Femen, have staged dramatic episodes of protest at the treatment of women by deploying sexuality and the female body as weapons of revolt.

This new wave of activism raises a range of political and analytic questions. How does it relate to, resemble and differ from earlier forms? What divides and unites the different generations involved in activism? How useful is the concept of 'waves', and what does a generational approach bring to an understanding of how feminisms relate to time and context? This research on the new feminist activism was undertaken for the Committee for the Status of Women (CSW) meeting for Beijing +25 . We titled the resulting paper, 'The New Feminist Activism: Intergenerational Perspectives', and this article is a shortened version of it [1].

In our research, we examined the existing scholarship on feminist movements, carried out original interviews with feminist activists, and analysed recent developments in Brazil, India, 
and Malawi. We asked if we are seeing the emergence of a 'Fourth Wave' of feminism, and identified critical continuities and seemingly new characteristics of contemporary feminist organising.

\section{Generations and waves: understanding feminism's evolution}

Feminism is a social movement with a long history, and has arisen in specific historical, social and political circumstances. Social movements are always time-bound phenomena, with periods of effervescence and of quiescence which invoke the metaphor of 'waves' to describe these temporal oscillations. Yet, as a 'travelling' or transnational movement, feminist ideas and activism radiated across continents over time with widely differing effects, complicating attempts to define waves and their time horizons.

As a modern social movement, feminism's early campaigns go back to the late $19^{\text {th }}$ century, and since then feminist movements have been more or less active at different points across time (Molyneux, 2002). In recognition of these periods of intense activism, Feminism is commonly described in terms of two main 'waves' - the first wave of the late-19 1 th $/$ early- $20^{\text {th }}$ centuries, the second starting in the late-1960s and early-1970s. To these have been added a third wave in the 1980s/1990s, with a fourth appearing in the new Millennium.

Unsurprisingly, it is disputed whether conceptualising feminism like this, in different waves, is useful, accurate or generalisable across regions. To deepen understanding of the different moments of feminism, there is value in adopting a generational approach to cast light on how social movements evolve, rise and decline. Such an approach draws attention to the materiality and the temporality of historical experience, embodied in a collective endeavour, with its specific challenges, optics, opportunities, political strategies and discursive configurations.

At its simplest, we can say that those who were young feminists in the 1960s and 1970s were shaped by their cultural context and history, and, as a consequence, thought and did things differently to those of later generations-even if they shared some common understandings that served to shape demands, priorities and approaches. This is why memory in the form of oral histories can be a valuable complement to feminist scholarship on specific movements [2].

\section{The new feminist activists: a fourth wave?}

The young feminists who have taken to the streets in recent years grew up in a different world to their mothers and a very different world to that of their grandmothers. While the generation that was active from the mid-1960s often clashed with their mothers over their social norms and values, young feminists today will have had a markedly different experience of family life. Their mothers may well have been feminists - or at least may have accepted, if not fought for-some of the movements' principles of equality and gender justice, and encouraged their daughters to adopt these principals themselves.

More broadly, what distinguishes the new Feminism from its antecedents are the social and political changes that it is heir to. Take education for example: young women, and hence 
young feminists are the most educated of any previous wave and, as education has expanded to broaden intake across social classes, Feminism has become both more socially diverse with a larger base, while containing a significant representation of young professionals (Milkman, 2017).

Feminists today-wherever they happen to be-live in societies that have undergone rapid social change in their own lifetimes. This has typically included a marked shift towards more liberal attitudes on sexuality and family forms, and more democratic, inclusive attitudes with respect to race and ethnicity. These changes are reflected in young feminist movements' direct embrace of struggles beyond those pertaining to women's rights, such as supporting LGBTQI+, and other identity movements, and being expressly committed to antiracist, egalitarian practices and politics. These strands were present in earlier waves of feminism, but less prominently so. Today although tensions may exist over some of these issues within contemporary Feminism, and 'radical inclusion' may not be embraced or practiced by all organisations, there can be little doubting the contrast with earlier Feminisms.

In addition, the changes in gender relations that have taken place are significant, even though they have not brought anything like full equality either in the private or public spheres. Women's roles have diversified perhaps more than men's, but the meaning of masculinity-what it means to be, behave and look like a man-has also diversified. While the high rates of domestic violence, feminicide, misogyny and rape are evidence that 'toxic masculinity' retains its virulence, many young men want more equal relationships with women. Where feminist campaigns depend on broad alliances for success, 'feminist men' can act as important allies.

Allies are especially important where feminism faces the rise of neo-conservative and rightwing forces that often draw on religious and populist tropes to campaign for reversals in women's rights, promising to restore patriarchal privileges and powers within the family and society. Many young feminists today face hostile governments, and see rights previously gained coming under attack. If previous generations can be said to have enjoyed more favourable conditions for advancing gender equality demands, this is far from true today.

Technological change, notably the global spread of the internet, has had a major impact on politics, enabling new forms of activism. Those born in this century are the first generation to have grown up entirely in the internet age. As many commentators have noted, young activists are tech and communications-savvy. They have at their disposal an array of social media and global networks which they have deployed to often great effect. These technologies have shaped their forms of collective activism and participation: social media can secure extensive grassroots engagement as well as reaching ever greater numbers compared to earlier forms of communication, -telephone, fax and print media. Flash demonstrations and viral videos like 'The Rapist is You' can be organised in minutes rather than days, and co-ordinated globally. Yet, young women are still disadvantaged by the digital divide, reinforced by out of date education and training initiatives, even as they are gaining ground in this domain (Keeley and Little eds 2017). 
The world of young feminists is one marked by a high degree of insecurity: the liberal reforms that have transformed labour markets and conditions, have eroded many former securities and welfare supports that their parents enjoyed if they worked in formal employment. Economic downturns and austerity policies exacerbate these effects, pushing up youth unemployment, migration and casualisation, and cutting short education. Young people are more indebted than earlier cohorts, burdened by consumer debt, and/or student debt. The 2008 economic crisis affected young people more than adults and with lasting effects: in Latin America, the youth unemployment rate (those aged 15-24 years) had reached nearly $20 \%$ by 2016 leaving one in every five young people unemployed (ILO, 2017). Deepening inequality and economic hardship impact on communities, driving the narcotics economy, crime and insecurity, and increasing the risks to which young people are vulnerable. If exciting opportunities may have opened up for those who can manage 'portfolio careers', and can prosper in the tech economy, for the many living with the 'new precarity', futures do not look so rosy.

At the same time, whereas former generations had more attachment to political parties and trade unions, this is far less the case among younger people, many of whom experience disenchantment with organised politics. Generational divides can make a difference to politics. In some countries, young people are more radical at both ends of the spectrum, and more critical of liberal capitalism. In the US, around half of millennials have a favourable view of socialism, and on other issues are also more progressive than the 'boomer' generation (born in the 1940s and 1950s) taken as a whole (Inglehart and Norris 2019).

This is of salience for the generational differences at play within feminist generations, as young people may be less committed overall to engaging with the very processes-legal change and 'engaging the state' or with the work of organisations like the UN-that were the focus of previous activist generations. Earlier gains in equal rights for example now seem to many young people to be limited in their real effects, or until the recent threats to them posed by rightist mobilisations, were simply taken for granted. Today, the picture is mixed and changing: at the individual level we are seeing young feminists running for and achieving high office in numbers not seen before. Moreover, some activists who become politicised through street politics find that this experience can be a prelude to entering other more formal political spaces.

History, experience and circumstance clearly mark out generational differences and present activists with situated challenges and opportunities which are bound to affect tactics, alliances, priorities, and forms of activism. Young feminists will necessarily do politics in different ways. Yet it is important to avoid oversimplifying the characterisations of different feminist waves and in doing so, exaggerating the divide between generations.

Feminism's history is one of diversity, and we should not take one strand to be representative of the whole movement even if it may have been a dominant one. Despite clear differences that mark out the generations, there are also continuities that link feminist movements. Young feminists may have less in common, and feel some distance with those feminists who entered the spaces of government or who were active in political parties and in 'development' work; but as our interviews attest, many still work with actors in these spaces to secure legal, political or cultural change. We need to examine the evidence for 
asserting that a rupture with previous histories of feminist activism has occurred in the present wave of activism, and understand more clearly how similar or different are the demands and tactics they pursue.

While critical differences mark out the Feminisms of different historical periods, a glimpse at the diversity that exists within the 'new Feminism', allows of no easy contrasts, or monolithic typologies; and there are, perhaps surprisingly, many continuities in Feminisms' core demands. The struggles for rights or to defend rights continue to be important for activists. The politics of the street is not the only form of activism undertaken by young feminists today, as the Ni Una Menos and Pro-Choice campaigns show with their emphasis on both activism and legal change. Campaigns around gender-based violence and reproductive rights may predominate today, but equal pay and job opportunities still constitute key areas of feminist organising. It is true that differences of strategy and tactics may demarcate generational boundaries; but even here, as the example of social media shows, it most often serves as an adjunct of more conventional forms or political mobilisation rather than substituting for them: street protests and social media campaigns are component parts of an often-rich repertoire of activism.

To illustrate some of the struggles and challenges of the current wave of activism, in what follows we analyse efforts to protect threatened rights in Brazil, campaigns around genderbased violence in India, and work to secure LGBTQI+ protections in Malawi. We show that, in spite of contextual specificities, ongoing feminist organising in the Global South shares some important characteristics - with other contemporary movements, as well as with previous generations.

\section{Brazil: Defending Rights Gained}

Latin America has a long and ongoing record of feminist activism, its early movements going back to the beginning of the previous century and even before in some countries (Baldez 2002). While during democratic transitions feminist activists fought for the inclusion of women's equal rights in new constitutions (Waylen 1994), when the left-wing presidents of the mid-2010s 'Pink Tide came to office, feminists worked alongside or within government institutions to demand the implementation of these rights (Friedman 2018).

However, as the 'Pink Tide' receded, evangelism continued to grow, and right-wing governments returned to power, women's incomplete protections-particularly those pertaining to gender-based violence and sexual and reproductive rights-became evident. Facing increasing backlash from culturally conservative forces (Molyneux 2017), in recent years, Latin America has seen large scale demonstrations demanding action to end violence against women and calling for an end to the criminalisation of abortion (Sanín 2019). In many ways, the Brazilian case is thus illustrative of broader regional patterns of feminist activism from the democratisation period to current times.

After re-democratisation in 1985, Brazil underwent significant political and societal changes which provided the conditions for feminist activism to flourish. It was during the governments of the Worker's Party (Partido dos Trabalhadores, PT), that feminist activists were most able to advance positive policy change. However, after 12 years of left-wing 
governments, Brazil faces a rise of conservatism and its first far-right president since the military dictatorship: Jair Bolsonaro.

Feminist activists, perhaps, were the first to notice (as well as respond to) the rise of conservatism in Brazil, a process that has reignited women's movements across the country. While Brazil's 'Feminist Awakening' was a gradual process, key events seem to have triggered, and maintained the strength, of collective activism. As Sueli Carneiro, founder and director of Geledés-Black Women's Institute, recently expressed:

Some 20 years ago, old feminists asked: 'where are the girls, where are the girls? What happened? They didn't arrive; they didn't come.' Now, I ask: 'you are so many, where were you hiding that we didn't see you?' And they say: 'we were growing-up' (Porto 2019).

The first sign of this awakening was women's collective response to a case of online sexual harassment. On 20 October 2015, when the first episode of Brazil's Junior Masterchef aired on television, a number of adult men tweeted sexual comments targeted at a 12-year-old girl competing on the show. Using \#FirstHarrasment (\#PrimeiroAssédio)-a campaign launched by the Feminist organisation Think Olga-women responded to the episode by using Twitter to recount their early experiences of sexual assault and harassment. In a fourday period, the campaign accumulated over 82,000 posts, increasing awareness about rape culture and girls' and women's shared experiences of early sexualisation in Brazil (M. Rossi 2015b).

Women rallied to fight against institutional violence. Just one day after women began mobilising online, a bill was proposed in Congress that would make it harder for victims of rape to access legal abortion (already one of the few exceptions protected by law). Women reacted by taking the streets. On 31 October 2015, it is estimated that more than 15,000 women marched on the streets of São Paulo and at least another 5,000 in other cities throughout the country (Martinelli 2015). Society paid attention and the media began speaking of the 'Feminist Spring' (Primavera Feminista).

Gender inequalities in Brazil had long been dire. For example, when protests began in 2015, Brazil ranked $8^{\text {th }}$ in the world in feminicide and officially registered over 500,000 cases of rape per year (M. Rossi 2015a), for a crime that is widely known to be underreported. Some progress however was made. When Lula was elected and the PT came to office in 2003, it established the Secretariat for Women's Policies, a ministerial-level institution specifically targeted at identifying and addressing gender-based inequalities. In parallel, the government also launched the National Conferences for Women's Policies meant to bring civil society into the policymaking process. It was also under Lula that the Maria da Penha Law, considered to be one of the strongest laws on domestic violence, globally, was enacted (Instituto Brasileiro de Direito de Família 2009).

Progress continued during Dilma Rousseff's terms. The appointment of Eleonora Menicucci, a public health professor who was more openly progressive on sexuality and reproductive rights to the Secretariat for Women's Policies was welcomed by feminists. It was also under Rousseff that a law was approved extending labour rights' protections to domestic workers, a sector overwhelmingly dominated by women of colour. 
It is undeniable that there were key advances during the PT years, but coalition politics, especially the PT's need to constrain advances in progressive areas to ensure the support of powerful Evangelical politicians, limited the government's actions on women's rights (Gatto, dos Santos, and Wylie 2017). The declining popularity of Rousseff's government led her to make further concessions to the coalition and, by the end of her government, the Secretariat for Women's Policies had vanished. Furthermore, feminists' close relations with the PT government may also have weakened organising at the grassroots. As Céli Pinto, Professor of History at the Federal University of Rio Grande do Sul and second-wave feminist and activist, explains:

There was the institutionalisation of the [Feminist] movement when the PT came into office [...] so you'd find feminist activists in all government institutions. But this also raises problems, because it had a generation of older women, from my generation and 10 years younger, working within the state apparatus [...] and the base [grassroots] was left a bit unprotected (Interview, Skype, 09 September 2019).

Still, as the Rousseff government began to decline, women's activism re-emerged as a key political force. When Rousseff was suspended from her duties in April, women went to the presidential palace to offer her flowers and staged a number of protests thereafter (Streit 2016). Soon after Rousseff's vice-president, Michel Temer, replaced her it became clear that the new government agenda would be in stark contrast to that of the feminist movement: Temer nominated an all-(white) male cabinet, and began enacting increasingly harsh austerity measures, prompting widespread protests.

Country-wide, women-led activism would re-emerge again in March 2018, when Councilwoman Marielle Franco was brutally assassinated. As women continued to mourn and demand answers about who was behind the murder of Marielle, they also had to contend with the Supreme Court's debate on the decriminalisation of abortion on 3 August-a process that was met with a series of threats directed at Débora Diniz, Professor of Law and a key expert testimony during the public audiences (Blower 2018).

When the October 2018 elections approached, however, all eyes turned to presidential campaigns. As then-candidate Jair Bolsonaro, who became internationally recognised for his misogynistic, racist, and homophobic comments (Forrest 2018) gained popularity, women organised again. Within a few days, a Facebook group called 'Women United against Bolsonaro' (Mulheres Unidas Contra Bolsonaro, MUCB) attracted roughly 4 million members, all women. Ludimilla Teixeira, founder of the MUCB Facebook group, highlights its successes in transforming online mobilisation into street activism (Interview, Salvador, 07 January 2020). from within the group, women organised the \#NotHim (\#EleNão) campaign, a hashtag that was used over 200,000 times in a single day on Instagram and in over 193,000 tweets over a span of three days (Uchoa 2018). Also through the efforts of the group, the largest women-led protests in Brazil's democratic history was organised, taking more than 100,000 people to the streets in São Paulo alone, and on 18 September, another 25,000 in Rio de Janeiro, and thousands more in at least another 144 cities from across the country (A. Rossi, Carneiro, and Gragnani 2018). 
On taking office and nominating Evangelical Pastor Damares Alves as Minister of Minister of Human Rights, Family and Women, Bolsonaro made his hostility towards feminists clear. On the day of her inauguration, Minister Alves emphasized stated that her time in office would represent the beginning of a new era when 'boys wear blue and girls wear pink' (Madov 2019). Since then, Minister Alves has made numerous declarations that sparked strong concern among feminists. The most recent case, in February 2020, consisted of the Ministry's announcement of the government's plan to test an abstinence-focused sex education curriculum (Bergamo 2020) - a policy that has largely been shown to be ineffective in reducing the initiation of sexual activity, teenage pregnancies, or the transmission of STIs (Stanger-Hall and Hall 2011).

The nomination of Damares Alves and the government's strong attempts (both through rhetoric and policy) to regulate expressions of gender and sexuality represents the institutionalisation of the anti-'gender ideology' movement that has grown in opposition to feminist forces in Latin America over the last few years, and that, in 2017, made international headlines after attacking and burning an effigy of the feminist philosopher Judith Butler during her visit to Brazil (Jaschik 2017).

In this context, when asked about the differences between the priorities of feminist activists in the 1970s and 1980s and now, second wave feminist academic and activist Cecilia Sardenberg, Professor of Anthropology at Federal University of Bahia, conveyed in interview: 'Back then, we fought to gain rights; now, we fight against them being taken away' (Interview, Skype, 09 September 2019).

In the 1980s, a key strategy employed by feminist activists to ensure the legal protection of women's rights in Brazil was what Pinto describes as the 'politics of presence'. As she recounts, during the process of writing the new Brazilian Constitution (adopted in 1988), there was at least one feminist activist present at every single meeting (Interview, Skype, 09 September 2019). Sardenberg added that, during this time, United Nations' meetings and conventions were instrumental to policymaking, as Brazilian women could take part in the collective planning of a global agenda for women's rights that they could then use to pressure domestic actors, in what she calls a 'boomerang effect' (Interview, Skype, 09 September 2019).

Now, feminists are combining traditional tactics with new ones: besides engaging in the 'politics of presence', by, for example, providing consultations to feminist congresswomen and attending congressional sessions (as Joanna Burigo, founder of the feminist online platform Casa da Mãe Joanna, does), young feminists are also using the web to put pressure in policy debates. For example, the Facebook bot Beta, sends invites to users to contact their representatives when bills limiting women's rights are scheduled to be debated in Congress. As well as raising awareness for causes through street demonstrations, women are now also designing and participating in viral online campaigns - such as the ones instanced above. While feminist academics continue teaching the new generations in classrooms, they are also making the knowledge available for free through online portals, including the Free Feminist University (Universidade Livre Feminista). Not only are women still engaged in international feminist networks through transnational organisations, but, 
through the use of social media, they also turn domestic issues into global trending topics that catch the attention of foreign media.

With this expansion in activism, the focus on democratising feminism has been brought to the forefront. Intersectionality now rests at the core of the movement. As mentioned in all interviews, Black Feminism has always been strong in Brazil, producing innovative and ground-breaking contributions to feminist theory, but, as Carneiro explains, Black Feminism emerged as a response to black women's exclusion from mainstream Feminism led by white women, and from black movements led by men (Porto 2019). Pinto recognises this:

Some more radical groups [of young feminists] criticise us [second-wave feminists] because we were white, middle class, and heterosexual. So, there is this criticism, and this is not an invalid criticism. To a large extent, we were indeed mostly [white, middle class, and heterosexual] (Interview, Skype, 09 September 2019).

While the plurality of Feminisms has always been evident, the heterogeneity of experiences and recognition of how institutional, structural, and social dynamics differently impact women is at the core of current movements. This is reflected in the popularity and success of the book series Plural Feminisms (Feminismos Plurais), curated by feminist philosopher Djamila Ribeiro. In this sense, a key characteristic of current feminist movements, has also been their capacity to incorporate various political agendas, including struggles against racism, for LGBTQ+ rights, and in defence of environmental protection.

Feminists have been under a state of alert since the election of Jair Bolsonaro - and all interviewees agree on the crucial importance of women's movements at this time, when there are signs that cases of domestic violence and sexual assault are increasing in the country (Mena and Barbon 2019). In this context, intergenerational learning and exchange may seems particularly key in the fight to maintain previously secured rights and push for more protections. As Carneiro recently expressed, now that the girls have grown-up, she is happy to pass on the baton to a new generation (Porto 2019). Cecilia Sardenberg agrees:

Now, we no longer have too much strength to run around. We go there [to demonstrations] and send messages online in support, because our legs cannot stand all the walking anymore. I am 71-years-old. [...] But we are there to support young women's movements [...] and we are happy to see that younger generations are continuing our fights. [...] This gives me hope that the fight will continue (Interview, Skype, 09 September 2019).

If recent events are any indication, the fight will indeed continue. As a new 'wave' of feminism takes back the streets of Brazil, new technologies accelerate the diffusion of ideas beyond the country's borders-allowing Latin American (and global) women to recognize, and build solidarity around, their common struggles.

\section{India: Gender-based Violence}

Ending violence against women has been a central and a long-standing campaign issue in India. When the UN declared 1975 as International Women's Year, the government of India commissioned a report on the status of women called 'Towards Equality' (Kelly \& Slaughter 
1992). This report played a catalytic role in the emergence of the contemporary women's movement in India. It was also during this time that India witnessed the formation of different kinds of women's organisations- trade unions, self-employed women's groups, Socialist/Marxists women's groups and even autonomous women's organisations (Omvedt 1986).

In keeping with the second wave of feminism, it was also during this period that violence against women became the central concern of the Indian women's movement with cases of custodial rape, state violence, gang-rape, dowry death and sexual harassment being taken up by feminist organisations across the country (Kumar 1993). Since then, feminist campaigns against violence against women can be categorised under 3 landmark cases The Mathura case which introduced the Criminal Law (Second Amendment) Act of 1983 defining the category of custodial rape and gang rape in individual rape cases; the Bhanwari Devi case which led to the introduction in 1997 of the Vishakha Guidelines, first comprehensive law against sexual harassment in the workplace; and the Nirbhaya case which led to the most substantive overhaul of Criminal Law in 2013.

On 16 December 2012, Jyoti Singh, a female physiotherapy student, was gang raped by six men while on a moving bus in New Delhi. After 13 days spent fighting for her life, Jyoti died. Abiding by Indian law, the real name of the victim was never used by the media and the most common pseudonym used was 'Nirbhaya' ('fearless') so the case came to be known as the Nirbhaya case. As soon it was reported by the media, thousands of people took to the streets of cities across India to protest the death of the innocent victim, women's lack of safety, women's rights and anti-rape laws. People from different sections of society, including women's organisations of different ideological persuasion, students' organisations, NGOs, labour unions, working men and women, individuals with no political affiliations and housewives came together spontaneously on the streets with a common purpose, to fight for gender justice.

The Nirbhaya case triggered, as Simon-Kumar states, "both the publicness and the personalisation of rape' $(2014,452)$ in a way that had not happened before, and the media (both mainstream media and social media) played a significant role in altering the public attitudes. The year 2012 saw the virtually connected Indian youth beginning to redraw the terms of engagement between the state and its urban population (Anwer \& Shrinivasan 2012). In the digital sphere, women in India started their fight by taking power back into their own hands through telling their stories, inspiring other women to do the same and demanding justice for the crimes committed against them. Hence, they started establishing a counter-narrative to the mainstream's silencing of victim/survivors and challenging dominant understandings of sexual and gender-based violence (SGBV) (Fileborn 2014). This 'testimonial' practice had first appeared in the 1980s, when the feminist movement in India used public discourse to 'break the silence' in cases of SGBV (Sen, 2017). However, after the Nirbhaya case this approach was reappropriated when young women across India started sharing their stories of abuse, creating in the process, communities of solidarity (Dey 2019).

With digital technology's increasing role in creating social and cultural narratives, we may also be seeing the emergence of a new kind of radical politics in India. Dalit groups in India have turned to alternative spaces online not only to challenge dominant discourses but also 
to build solidarities nationally and transnationally (Mishra 2017). New media has also had significant impact on queer communities in India providing them avenues not only to establish their own political narratives but to carve out a social space for interaction and dialogue (Dasgupta 2017).

The Nirbhaya case not only had significant impact on public discourse and awareness, but also had substantial legal impacts leading to the most rapid and substantive overhaul of Criminal Law. However, two most important recommendations that were excluded from the new law relate to marital rape and rape by armed forces. Marital rape was not included in the amendments, as the lawmakers decided that it would potentially disrupt the institution of marriage and the entire family system in India, thus denying that rape can occur within the sacred bonds of marriage. The armed forces, especially in the 'disturbed areas' are still effectively immune from prosecution for rape and sexual assault, as they are protected by special laws, such as the Armed Forces (Special Powers) Act of 1958.

This shows that while the state and lawmakers are willing to engage in legal or punitive measures for crimes around SGBV, having broader conversations around regressive patriarchal practices or state violence is still largely impossible. Many feminists have pointed out that post-Nirbhaya, the demand for the death penalty for perpetrators of rape in effect diluted the movement, taking attention away from larger questions of patriarchal oppression and structural violence.

However, the Nirbhaya case and the mobilisations that followed succeeded in creating a gender-dominated agenda through public discourse in India. What followed for the next few years was a series of youth driven feminist campaigns largely emanating from the gender politics of university campuses. Campaigns such as \#HokKolorob (let there be noise), \#PadsAgainstSexism, \#HappytoBleed, \#WeWillGoOut, \#AintNoCinderella or larger movements such Pinjra Tod (Breaking the cage) have all used social media and catchy hashtags in creative ways to spread awareness and conversations about important issues such as silence around menstruation, women's rights to public spaces, setting up of sexual harassment committees in universities, and women rights to freedom and mobility. Hence, in 2017 when the \#MeToo movement spread globally, young Indian women were prepared. The anger that was already brewing found its perfect manifestation through \#MeToo.

On 24 October 2017, Raya Sarkar, a 24-year-old law student of Indian descent at the University of California, posted a crowd sourced list on Facebook of male academics in Indian Universities who allegedly harassed or assaulted women. The 'list', as it came to be known, was the result of a broken academic system that routinely failed to hold sexual predators to account. However, instead of bringing the feminist community together the 'list' showed the world the crevasses of Indian feminism particularly on generational lines.

A group of Indian feminists (who came to be referred to as the older feminists in the debate) vehemently disagreed with the politics of the 'list' and said that it devalued 'due process'. Debates raged on social media such as Facebook and Twitter, with arguments for and against the 'list'. However, as Ritty Lukose $(2018,38)$ states, 'the fractious media discourse around older feminists who worry about 'moral panic' and sexual regulation 
versus 'younger' feminists who too easily speak a language of exploitation and victimhood belies a more complex understanding of how sexual politics has changed over time'.

Much of the feminist movement in India historically has focused on changes in law. This was the priority of the time as laws on gang rape, custodial rape, domestic violence, sexual harassment in the workplace were not only inadequate but, in some cases, non-existent. However, the challenge to the new wave of feminists has been the lack of implementation of laws and fighting patriarchal practices that still form a major barrier to prevention, prohibition and redress of SGBV. It is this aspect that younger feminists supporting the list tried to address. In a society that is still segregated and divided in the lines of gender, class, caste, ethnicity, religion and nationality among others, power dynamics and hierarchies make it impossible for many women to access formal complaints procedures and legal mechanisms. Hence, simply the presence of due process does not ensure that justice needs are met.

However, the current phase of feminist movements in India cannot be understood without looking at the larger social and political context. In 2014, Narendra Modi's Bharatiya Janata Party (BJP) came into power in a landslide victory. The BJP, a right-wing, conservative political party, brought with it a steep rise in Brahmanical Hindutva nationalist politics and the communities who have borne the brunt of it the most have been Hindus from the lowest caste or Dalits (untouchables), Muslims, women and queer communities. Modi previously the chief minister of the state of Gujarat was accused of initiating and condoning the bloodshed that followed the 2002 Gujarat riots, one of the most brutal episodes of modern India in which more than a thousand people died.

The riots also witnessed extensive and specific targeting of women, young girls and children, who were subjected to the most sadistic and vicious forms of sexual violence. Since coming into power, several elected ministers of the BJP have made casual comments on rape and have openly indulged in blatant misogyny and victim blaming. BJP MLA, Kuldeep Singh Sengar has been accused of raping a 17-year-old girl in Unnao. In Jammu and Kashmir, BJP state ministers marched in support of men who gang-raped and murdered an innocent child in Kathua. The Uttar Pradesh chief minister's answer to violence against women were 'antiRomeo squads' leading to further policing and securitisation of women and to the beating up of young couples who cross caste/community lines.

Considering this background, it is indeed an interesting time to look at the Indian feminist movements. Irrespective of many debates and disagreements, the Indian urban feminist movement has seen a recent revival. This is largely an urban upper-class, upper caste movement (Dhanaraj 2018)but it is important to note the continued resistance by women in Kashmir, Northeastern India, tribal women, Dalit communities, Muslim communities and other minority communities across the country. Several campaigns and collectives led by young feminists working on a grassroots level are focusing on challenging everyday normalised violence and empowering women.

One such movement is Pinjra Tod (PT) ('break the cage'). To fight against the security narrative and reclaim public spaces, in 2015, a group of women students and alumni from colleges across New Delhi came together to form this autonomous women's collective. 
When the movement started to reclaim the night, women marched through Delhi University campuses at night rattling hostel locks and banging on the doors, shouting slogans, beating drums, singing, reciting poetry and even breaking into impromptu dances. Describing their marches, a PT activist said, 'ours is a jubilant movement'.

However, PT is not a single-issue based movement. A look at its social media pages reveal the diversity of issues that they engage with- resisting the BJP government right-wing nationalism, protesting against fee hikes, neoliberalisation and privatisation of education, speaking out about the Indian states unconstitutional move in Kashmir with the abrogation of Article 370 and 35, and joining the sanitation workers on strike- they are all feminist issues and that is perhaps the biggest strength of movements like PT.

Asked about what was new, and what were the differences with earlier movements in India, one young activist said:

I would say that the methods of working and bringing about change are different as compared to the earlier waves. For example, if you look at the context of the Me Too movement, the methods are very different. There is much more openness in the new wave compared to the older wave. The older wave had particular ways of functioning and they were very reluctant to change. So that's the difference I see. The new feminist movement is also aligning with other movements such as the LGBT movement which was not done earlier. Now also it is not done in the best way but at least an effort is being made to collaborate and work together (Interview, India, 13 September 2019).

Moving away from focusing mainly on legal or punitive approaches, some of these new movements are trying to be inclusive and intersectional. Their focus is on cultural change through constructive political collective action. Through this they are giving women a voice, building solidarities across boundaries and allowing women who have suffered abuse to heal. They are looking for more creative and community-based solutions that result in a change of culture rather than simply changing laws, while not forgetting to question caste, class, religion, sexuality and disability. While these movements are not without their own shortcomings, the voices of dissent that emerge out of them are loud, strong and determined.

At the time of writing in February 2020, thousands of Indian women are involved in the protests against the Citizenship (Amendment) Act (CAA), the National Register of Citizens (NRC) and the National Population Register (NPR). Activists and lawyers, students, housewives, mothers, grandmothers and children, across India have been at the forefront of this resistance. For many, it is the first time they have had any political engagement. This has been epitomised in the neighbourhood of Shaheen Bag in New Delhi where hundreds of Muslim women blocked a main road since December and began a sit-in demonstration. Shaheen Bag is not only a site of protest, but also community of love, solidarity, and joy; a site of political education and collective learning. Since then many Shaheen Bag style occupations have started across Muslim communities in India and they have been mostly led by women. Slogans of Azadi (freedom) reverberate in streets across the country and the voices of women loudly assert-'Ladenge, Jitenge' (We shall fight, we shall win). 


\section{Malawi: LGBTQI+ and feminist activism}

The complex interactions and collaborations between feminist and LGBTQI+ activists further complicate the notion of clearly defined generational 'waves' of activism, bringing into sharp relief tensions over priorities and tactics. At the same time, an evaluation of the new feminist activism of the 'Fourth Wave' demonstrates a marked shift towards making 'radical intersectionality' a lived reality, and an alignment of ongoing demands related to sexual health, reproductive rights, violence against women, and social mobility.

Across the global south, important gains have been made by advocates for LGBTQI+ rights, alongside advances in women's rights more broadly. The 1985 UN Third World Conference on Women in Nairobi saw the affirmation of the existence of lesbian identities in Kenyan society (Salo; Dineo Gqola 2006). A decade later, sexual orientation became a topic of debate in negotiations on the draft of the 1995 Beijing Platform for Action. South Africa, along with Brazil, led the way in June 2011 to galvanise the UN Human Rights Council to explicitly commit to the principle of protecting the right to freedom from discrimination on the basis of sexual orientation (Epprecht 2013, 1).

Nevertheless, in the wake of the 1995 Beijing Women's conference, many activists felt that sexual matters were not a priority, an attitude that has proved persistent in subsequent years (Jolly 2000,10$)$. The first two decades of the twenty-first century have seen a resurgence of anti-LGBTQI+ discrimination and legislation criminalising same sex relations in countries in the Global South, many on the African continent. In 2009, an Anti-

Homosexuality bill was proposed in Uganda. and has been repeatedly reintroduced. In 2015, Ugandan activists attempted to organise the country's first pride parade, which was disrupted and followed by a violent police crackdown. Organisers were forced to cancel the planned parade again in 2019 due to safety concerns. A Same Sex Marriage Prohibition Bill also passed in the Nigerian Senate in 2011, while in South Africa there has been an alarming rise in incidents of 'corrective rape' targeting lesbians as well as cases of forced conversion therapy.

Sexuality and gender identity remain highly contested in post-colonial and post-apartheid contexts. Alongside the increasing visibility of African feminists and LGBTQI+ activists, there has also been a growing presence and intervention by what has been termed the 'Gay International' (Epprecht 2013, 85). Defined as white, Northern-based NGOs and activists with an overt interest in searching for homophobia across the Global South, this has hindered some efforts to integrate LGBTQI+ rights into human rights discourses without side-lining the complex colonial legacies and local contexts in countries where discrimination based on sexual orientation or gender identity remains strong (Ekine 2013, 85). In the same way, reliance on financial aid from western NGOs has meant aid conditionality often plays a role in political decisions about open support of LGBTQI+ rights among feminist groups. Visibility is still a complex double-edged sword for both feminists and LGBTQI+ activists, particularly as renewed attacks on sexual minorities 'in the name of national or African or traditional values' have frequently been part of more generalised attacks on Feminism, gender equality, and religious and civil freedoms (Epprecht 2013, 5). As a result, feminists across numerous African countries have often taken ambivalent positions on LGBTQI+ issues. 
In 2010, a Malawian transgender woman, Tiwonge Chimbalanga, and her male partner, Steven Monjeza, were put on trial and found guilty of 'gross indecency', following their public wedding engagement ceremony. Although Chimbalanga identified as a woman, she and Monjeza were labelled as a same-sex couple and sentenced to 14 years imprisonment, although they were later pardoned by then president Bingu wa Mutharika amidst international pressure and condemnation. The case gave a renewed impetus to the politicisation of homosexuality in Malawi, resulting in protests and police repression, which strained cross-movement solidarity partnerships as some activist organisations grew increasingly concerned about supporting LGBTQI+ rights.

Complex pressures underpin activists' decisions to publicly foreground certain facets of identity and these have been particularly apparent in the case of African feminist engagement with LGBTQI+ rights. One Malawian feminist activist, Linda, explained her organisation's reluctance to openly support Chimbalanga and Monjeza, by highlighting the risk of encountering hostility from local political or religious leaders, on the one hand, and disapproval from western NGOs on the other if not vocal enough about their support of LGBTQI+ issues. Remaining silent, or packaging support in a less explicitly LGBTQI+ framework thus insulated Feminist groups from accusations of "promoting homosexuality" in Malawi (Currier, 2014, 155). Indeed, other activist organisations argued that deferring explicit public support for LGBTQI+ rights and advocating for the inclusion of sexual minorities in HIV/AIDS provision constituted a more acceptable way to engage in LGBTQI+ advocacy (Currier, 2014).

The treatment of Tiwonge by the media and the judicial system is also an illustration of the intersections between anti-LGBTQI+ legislation and social attitudes, exemplified by the fact that she was perceived and labelled a gay man even though she explicitly identified as a woman. Malawian activist Linda explained that her organisation perceived Chimbalanga and Monjeza as men, and therefore did not feel they were an immediate priority, but she would have supported a lesbian charged with breaking the country's anti-LGBTQI+ laws; 'next time they try and prosecute a lesbian, l'll be in the forefront defending this particular person' (Currier 2014, 157).

Arguably, one of the most contentious debates between different generations of African feminists across the continent has been over gender identity and expression, which cuts right to the heart of feminist theorising about what 'makes' a woman. To cite another illustrative example, Nigerian feminist and author Chimamanda Ngozi Adichie has been a vocal opponent of Nigeria's anti-gay laws and advocate for gay rights, although she was criticised by Nigerian LGBTQI+ activists and international feminists in 2017 after an interview in which she addressed the question of whether transgender women should be considered as 'women'. Adichie asserted 'trans women are trans women' and expressed concerns about conflating trans women's experiences to women who have been socialised as female 'from the beginning' (BBC, 16 March 2017). Her comments sparked a passionate online debate, bringing to the fore disputes between some of the older feminists representing a more essentialist definition of gender based on biological sex, and many younger 'intersectional' LGBTQI+ feminists. 
Despite the complicated ambivalence of some feminist groups, many activists did openly support Chimbalanga and her partner, embracing the new opportunities afforded by technology to raise awareness and share information. This included Gender Dynamix-the first African organisation focusing solely on the rights of transgender and gender nonconforming people-and online witness change project 'Where Love is Illegal' which later shared a photo entry of Tiwonge, providing an online platform for her to tell her story. The Centre for the Development of People (CEDEP), launched in Malawi in 2006 out of a collective desire to create a 'movement that [gives] a voice to...other [sexual minorities] who are not able to speak out' supported the couple throughout their trial (McKay, 2017, 12). This was not without negative consequences, as the presence of NGOs can often complicate local politics, and CEDEP's involvement did cause unwelcome, negative attention for LGBTQI+ Malawians.

However, CEDEP's initially cautious role in the legal defence of Chimbalanga and Monjeza also represented an important 'new pathway' for strategic action, and a more radically inclusive approach to human rights and feminist activism in Malawi. Primarily engaged in public health advocacy and HIV/AIDS research prior to 2010, CEDEP embraced its heightened public visibility following the Chimbalanga case to pursue expanded socialjustice advocacy, paving the way for other activist organisations (M,cKay, 2017). Over the last few years, CEDEP has cosponsored events commemorating the International Day of Homophobia and Transphobia in Malawi, while in 2014, the organisation led others in demanding the decriminalization of same-sex sex (Namangale 2014). In 2016, CEDEP published the book Proudly Malawian: Life Stories from Lesbian and Gender-Nonconforming Individuals, documenting stories of survival in harsh realities, and demonstrating an increasing willingness to support the shared, as well as contrasting, experiences of different groups of Malawian women.

The evolving responses to the Chimablanga case in Malawi can be understood in conjunction with a growing, continent-wide 'activist-scholarly engagement' with 'subaltern sexualities' (Dineo Gqola 2006, 5). Many young feminists have mobilised in direct response to the backlash against LGBTQI+ rights and women's bodily autonomy. Responding to South African lesbian activist Palesa Beverley Ditsie's call to acknowledge lesbians' human rights as a key part of the struggle for women's rights at the 1995 Beijing Women's conference, many African feminist organisations have crafted a more inclusive platform. Despite heightened violence, discrimination, and criminalisation in many African countries, there has been 'assertive' intergenerational engagement with the state, civil society, queer communities, and international NGOs.

One powerful example of this can be found in the work of Sister Namibia, the first feminist organisation to support LGBTQI+ rights in Namibia. The organisation established a Lesbian Support Programme, running local and national workshops, and founded human rights initiative Rainbow Project (TRP) in 1997, both designed to deliberately nurture 'a new generation of young lesbian women who are prepared to speak publicly for their rights' (Khaxas 2006, 85). Comparably, the African Feminist Forum, which has been a vocal supporter of LGBTQI+ issues, launched an 'African Feminist Ancestors' project based on a commitment to ground feminist activism, movement-building, and strategies on lessons 
from previous generations and the ways that past feminist activists and African women have negotiated power.

While the characteristics of much of this new feminist activism can be understood by looking at the evolving strategies of younger generations, critical attention should still be paid to the ways that the idea of 'generation' itself has been invoked in complex ways within nationalist anti-LGBTQI+ arguments across the African continent. The notion that Feminism is distinctly 'new,' even if African women's activism has a long and rich history, rhetorically pits feminist activism against nationalisms or nation-building imperatives. This stance was exemplified by Prime Minister of Zimbabwe Morgan Tsvangirai when he suggested that 'when people have no food...no jobs... when people have so many problems', placing sexual rights at the forefront of the national agenda is a 'diversionary attitude' that distracts from more important issues (Epprecht 2013, 2).

In 1994, postcolonial feminist M. Jacqui Alexander posed the question: 'in the absence of visible lesbian and gay movements, can feminist political struggles radically transform these historically repressive structures?' (Lorway 2014, 85). Revisited now, her question alerts us to the vibrant, dynamic activism happening at the grassroots, while also giving responses to the anti-LGBTQI+ backlash happening in many African countries a particular sense of urgency. The defensive, cautionary framing of much of the LGBTQI+ activism across the African continent in recent decades can in part be accounted for by this backlash and the sense that existing gains are under threat, or that new gains are being pre-emptively undercut.

Social media has afforded new and dynamic platforms for mobilisation and solidarity, although this has also exposed fault lines of access and class. In recent years, hashtags like \#BringBackOurGirls and \#FeministWhileAfrican, have brought issues affecting African women and girls into the international spotlight as well as demonstrating some of the tensions that exist within African Feminisms over terminology and self-identification. The dynamics within and across Feminist and LGBTQI+ movements resist any simple conclusions or generalisations, although what has united many of these activists across Africa, in countries like Malawi, is an increasing willingness to adopt a more intersectional approach and utilise new strategies and technologies to pursue overlapping demands.

\section{Conclusions}

The history of feminism cannot be written without taking account of the experiences of those who participated in it, as activists, theorists, and policymakers, among others. Each generation of activists has its own perspectives shaped by the myriad influences that it is subjected to and the opportunities it has to bring positive change. For those living in enabling environments, much can be achieved, but for those facing attacks on women's rights as is the case in so many regions today, the battle is to defend the gains won by a previous generation: the lines between past and present are here not too starkly drawn.

Should we be speaking about the new activism as a 'new wave' or a 'new generation' of feminism? A decade or so ago, Feminism was declared 'dead' and passé, as the 'Post Feminist Age' was confidently asserted. How wrong these claims have proven to be. At the 
time of writing, it seems clear that Feminism has seen a remarkable revival in a good number of regions and that a new wave is under way. Moreover, Feminisms have a significant presence at the global level given effective transnational networks and the shared nature of contemporary concerns such as gender-based violence, sexual rights and struggles to defend feminist gains that are now under threat. Our Indian and Brazilian cases show that the large-scale protests that have erupted over sexual violence and threats to rights, are rooted in longer struggles that go back decades - they have not just appeared from nowhere, and nor do they vanish without trace after the protesters have left the streets.

As is true of earlier times, these social movements bring together a variety of disparate actors and deploy a range of tactics often working in different spaces to pursue their objectives. Neither Brazil nor India are optimal environments for defending, let alone advancing, women's rights, diversity and equality agendas, but nor is Malawi. These cases underline just how important rights' frameworks can be for people who suffer discrimination and persecution in challenging and dangerous contexts. Movements for justice, however small their numbers, can often achieve positive change. As all three cases show we see how important social media can be for contemporary movements, providing an invaluable resource for networking, information exchange and mobilisation. But in the wrong hands it can also be a new weapon of anti-feminist opposition.

In focusing on the new activism it is clear that despite varying priorities and interpretations, there are some striking similarities in feminists' demands that span countries, regions and decades. This speaks to the enduring character of gender inequality and the slow progress made in achieving feminist demands. A quarter of a century on from Beijing, it is not only surprising, but also deeply worrying to see the high levels of gender-based violence, the lack of adequate sexual and reproductive rights and services in many countries, the continuing wage gap, and the very limited progress in acknowledging the need for affordable and gender equitable care. This is not to deny that progress has been made in many areas, but it has not been sufficient to warrant dismissing Feminism as 'over'.

A second point concerns human rights frameworks. Feminist movements have always engaged in rights demands, and feminists were active in the drafting of the 1948 Universal Declaration of Human Rights [3] and in the Beijing process. Over time, human rights frameworks have been adapted and extended to be more comprehensive and inclusive, they have been tested in the courts, and they have been challenged by those who oppose them, but more often than not it is women's movements and their campaigns, allies and resources that have played a critical role in securing and defending advances in women's rights. These, in turn, have served as a lever to advance further gains, raise awareness, and challenge discriminatory norms.

While the human rights movement has lost some momentum and some of its more radical champions within human rights' institutions, feminist activists continue to work within their respective domestic and regional spheres to advance (and preserve) women's rights. Their work in defending human rights has become particularly urgent at a time when powerful states seek to undermine and roll back rights and the global architecture on which they rest. As the new wave of activism has shown, rights have continued to be central to all forms of 
justice claims-whether in regard to Feminist or many other forms of contemporary youth activism.

\section{Endnotes}

[1] The authors are preparing a CSW Research Paper on these themes to be published online later this year. The longer draft of the paper Molyneux presented at the CSW conference can be found at: https://www.unwomen.org//media/headquarters/attachments/sections/csw/64/egm/molyneux\%20mbac kground\%20papersecond\%20draftbp2.pdf?la=en\&vs=1228

[2] Maxine Molyneux is the co-ordinator, working with feminists in Chile and Mexico, of an archive of intergenerational dialogues, as part of the Samuel Proctor Oral History Program at the University of Florida.

[3] Available at https://www.ohchr.org/EN/UDHR/Documents/UDHR Translations/eng.pdf (last checked 22 February 2020).

\section{Notes on authors}

Adrija Dey is a British Academy post-doctoral research fellow and a senior teaching fellow at the SOAS Department of Development Studies. She can be reached at Ad84@soas.ac.uk.

Malu A. C. Gatto is Assistant Professor in Latin American Politics at the UCL Institute of the Americas, University College London (UCL). She can be reached at m.gatto@ucl.ac.uk.

Maxine Molyneux is Professor of Sociology at the UCL Institute of the Americas, m.molyneux@ucl.ac.uk.

Holly Rowden is a freelance researcher. Her email is hollylrowden@gmail.com

\section{Bibliography}

Anwer, Javed, \& Shrinivasan, Rukmini. (2012). "The year social media came of age in India." http://articles.timesofindia.indiatimes.com/2012-12-31/social-media/36078534_1_socialmedia-tweet-flash-mob

Baldez, Lisa. (2002). Why Women Protest: Women's Movements in Chile. Cambridge University Press.

Bergamo, Mônica. (2020). “Damares Quer Lançar Plano de Abstinência Sexual No Norte e Nordeste." Folha de S.Paulo.

https://www1.folha.uol.com.br/colunas/monicabergamo/2020/02/damares-quer-lancarplano-de-abstinencia-sexual-no-norte-e-nordeste.shtml. 
Blofield, Merike, Christina Ewig, and Jennifer M. Piscopo. (2017). "The Reactive Left: Gender Equality and the Latin American Pink Tide." Social Politics, Vol. 24(4), pp. 345-69.

Blower, Ana Paula. (2018). “Debora Diniz: 'Não Há Como o STF Ignorar o Que Foi Apresentado.'” O Globo. https://oglobo.globo.com/sociedade/debora-diniz-nao-ha-comostf-ignorar-que-foi-apresentado-22955525.

Chaudhary, Suresh K., \& Subramani, Raja. (2014). "Internet as an alternative media for dalits in India: Prospects and challenges." Journal of Humanities and Social Sciences, Vol. 19(2), pp. 125-129.

Currier, Ashley. (2014). "Arrested Solidarity: Obstacles to Intermovement Support for LGBT Rights in Malawi." Women's Studies Quarterly, Vol. 42, pp. 146-163.

Currier, Ashley and McKay, Tara. (2017). "Pursuing Social Justice through Public Health: Gender and Sexual Diversity Activism in Malawi." Critical African Studies, Vol. 9, pp. 71-90

(Dhanaraj, Christina Thomas, (2018)

https://www.firstpost.com/india/metoo-and-savarna-feminism-revolutions-cannotstart-with-the-privileged-feminist-future-must-be-equal-for-all-5534711.html

Dasgupta, Rohit. K. (2017). Digital queer cultures in India: Politics, intimacies and belonging. Routledge India.

Dey, Adrija. (2019). Nirbhaya, New Media and Digital Gender Activism. London. Emerald Publishing.

Ekine, Sokari. (2013). "Contesting Narratives of Queer Africa" in Queer African Reader. Pambazuka Press.

Epprecht, Marc. (2013). Sexuality and Social Justice in Africa: Rethinking Homophobia and Forging Resistance. Zed Books.

Félix de Souza, Natália Maria. (2019). "When the Body Speaks (to) the Political: Feminist Activism in Latin America and the Quest for Alternative Democratic Futures." Contexto Internacional, Vol. 41(1): pp. 89-112.

Fileborn, Bianca. (2014). “Online activism and street harassment: Digital justice or shouting into the ether?" Griffith Journal of Law \& Human Dignity, Vol. 2(1).

Forrest, Adam. (2018). "Jair Bolsonaro: The Worst Quotes from Brazil's Far-Right Presidential Frontrunner." Independent.

https://www.independent.co.uk/news/world/americas/jair-bolsonaro-who-is-quotes-brazilpresident-election-run-off-latest-a8573901.html.

Frank, Liz and Khaxas, Elizabeth. (2006). "Sister Namibia: Fighting for All Human Rights for All Women." Feminist Africa, Issue 6, pp. 83-86.

Friedman, Elisabeth Jay, (ed.). (2018). Seeking Rights from the Left: Gender, Sexuality, and the Latin American Pink. Duke University Press.

Inglehart, Ronald and Pippa Norris. (2019). Trump, Brexit and Authoritarian Populism Cambridge. Cambridge University Press. 
Instituto Brasileiro de Direito de Família. (2009). "Para ONU, Lei Maria Da Penha é Uma Das Mais Avançadas Do Mundo." Jusbrasil.

https://ibdfam.jusbrasil.com.br/noticias/2110644/para-onu-lei-maria-da-penha-e-uma-dasmais-avancadas-do-mundo.

International Labour Office. (2017). World Employment and Social Outlook 2017. Geneva. ILO.

Jaschik, Scott. (2017). "Judith Butler on Being Attacked in Brazil." Inside Higher Ed.

https://www.insidehighered.com/news/2017/11/13/judith-butler-discusses-being-burnedeffigy-and-protested-brazil.

Jolly (2000) in Okech, Awino. (2013). "In Sisterhood and Solidarity': Queering African Feminist Spaces” in Ekine, Sokari; Abbas, Hakima. Queer African Reader. Pambazuka Press.

Keeley, Brian and Little, Céline, (eds.). (2017). The State of the World's Children 2017: Children in a Digital World. New York. UNICEF.

Kelly, Gail. P., \& Slaughter, Sheila. (1992). Women's higher education in comparative perspective. Dordrecht. Kluwer Academic Publishers.

Kumar, Radha. (1993). The History of Doing: An Illustrated Account of Movements for Women's Rights and Feminism in India, 1800-1900 (1st ed.). New Delhi. Kali for Women.

Lorway, Robert. (2014). Namibia's Rainbow Project: Gay Rights in an African Nation. Indiana University Press.

Lukose, Ritty (2018). "Decolonizing Feminism in the\# MeToo Era." The Cambridge Journal of Anthropology, Vol. 36(2), pp. 34-52.

Madov, Natasha. (2019). "'Boys Wear Blue and Girls Wear Pink,' Says Human Rights Minister." Folha de S.Paulo.

https://www1.folha.uol.com.br/internacional/en/brazil/2019/01/boys-wear-blue-and-girlswear-pink-says-human-rights-minister.shtml

Martinelli, Andréa. (2015). "14 cartazes da "Primavera das Mulheres" que mostram por que a "PL do Aborto" não pode ser aprovada." Huffington Post Brasil.

https://guce.huffpostbrasil.com/copyConsent?sessionld=3_cc-session_964da345-77304a13-9e14-402a34e337d3\&inline=false\&lang=pt-pt.

McLean, N, and Mugo, T. K. (2015). "The Digital Age: A Feminist Future for the Queer African Woman". IDS Bulletin, Vol. 46, pp. 97-100.

Mena, Fernanda, and Júlia Barbon. (2019). "Morte de Mulheres Dentro de Casa Cresce 17\% Em Cinco Anos." Folha de S.Paulo.

https://www1.folha.uol.com.br/cotidiano/2019/06/morte-de-mulheres-dentro-de-casacresce-17-em-cinco-anos.shtml.

Milkman, Ruth. (2017) “A New Political Generation?” American Sociological Review, Vol. 82(1), pp.1-31. 
Mishra, Bikram K. (2017). Digital Media in Resisting Social Inequality the Indian Experience. Springer.

Mohan, Megha. (2017). "Why Transgender Africans Turned Against a Famous Feminist." BBC News. https://www.bbc.co.uk/news/blogs-trending-39271690.

Molyneux, Maxine (2002) Women's Movements in International Perspective Palgrave: New York and London.

Molyneux, Maxine. (2017). "The Battle over 'Gender Ideology.'” International Politics and Society. https://www.ips-journal.eu/regions/latin-america/article/show/the-battle-overgender-ideology-2472/.

Naqvi, Farah. (2019). "For the BJP, "Women's Rights" Are Really All About the Men." https://thewire.in/women/elections-2019-bjp-womens-rights

Nyeck, S.N. and Marc Epprecht (eds.) (2013). Sexual Diversity in Africa: Politics, Theory, Citizenship. McGill-Queen's University Press.

Omvedt, Gail. (1986). Women in popular movements: India and Thailand during the decade of women. In S. Staab \& S. Razavi (Eds.), Gendered Dimensions of Development (pp. 211239). United Nations Research Institute for Social Development.

Porto, Walter. (2019). "Não Dá Para Falar de Feminismo Sem a Mulher Negra, Diz Sueli Carneiro." Folha de S.Paulo. https://www1.folha.uol.com.br/ilustrissima/2019/11/nao-dapara-falar-de-feminismo-sem-a-mulher-negra-diz-sueli-carneiro.shtml.

Rossi, Amanda, Julia Dias Carneiro, and Juliana Gragnani. (2018). “\#EleNão: A Manifestação Histórica Liderada Por Mulheres No Brasil Vista Por Quatro Ângulos." BBC Brasil.

https://epocanegocios.globo.com/Brasil/noticia/2018/09/elenao-manifestacao-historicaliderada-por-mulheres-no-brasil-vista-por-quatro-angulos2.html.

Rossi, Marina. (2015a). “As Mulheres Brasileiras Dizem Basta Os Motivos Nunca Faltaram, Mas, Na Última Semana, o Grito Foi Às Ruas." El País.

https://brasil.elpais.com/brasil/2015/11/03/politica/1446573312_949111.html.

- - . (2015b). "O Dia Em Que Relatos Do Primeiro Assédio Tomaram Conta Do Twitter." El País. https://brasil.elpais.com/brasil/2015/10/22/politica/1445529917_555272.html.

Salo, Elaine, and Dineo Gqola, Pumla. (2006). "Editorial: Subaltern Sexualities." Feminist Africa, Issue 6, pp. 1-6.

Sen, Rukmini. (2017). "Sexual Harassment and the Limits of Speech. Economic \& Political Weekly." Economic \& Political Weekly, Vol. 52(50).

Simon-Kumar, Rachel. (2014). "Sexual Violence in India: The Discourses of Rape and the Discourses of Justice." Indian Journal of Gender Studies, Vol. 3(21), pp. 451-460.

Stanger-Hall, Kathrin F., and David W. Hall. (2011). "Abstinence-Only Education and Teen Pregnancy Rates: Why We Need Comprehensive Sex Education in the US." PLOS ONE, Vol. 6(10).

Streit, Maíra. (2016). "Mulheres Homenageiam Dilma Com Flores em Brasília." Fórum. https://revistaforum.com.br/noticias/82367/. 
Tamale, Sylvia (ed). (2011). African Sexualities: A Reader. Oxford. Pambazuka Press.

The Universal Declaration of Human Rights.

Uchoa, Pablo. (2018). "Jair Bolsonaro: Why Brazilian Women Are Saying \#NotHim." BBC. https://www.bbc.co.uk/news/world-latin-america-45579635.

Waylen, Georgina. (1994). "Women and Democratization Conceptualizing Gender Relations in Transition Politics." World Politics, Vol. 46(3), pp. 327-54. 